\title{
Platelet Adhesiveness, Plasma Fibrinogen and Factor VIII Levels in Diabetes Mellitus
}

\author{
E.E. MaYni, J.M. Bridges and J.A. Whaver
}

\author{
The Department of Clinical Pathology and Sir George E. Clark Metabolic Unit, Royal Victoria Hospital, \\ Belfast, N. Treland
}

Received: September 10, 1969

\begin{abstract}
Summary. Platelet adhesiveness and the levels of two coagulation factors, fibrinogen and factor VIII, were studied in a series of diabetic and nondiabetic control subjects. All three measurements were significantly abnormal in the diabetic patients. The increase in platelet adhesiveness was capable of distinguishing the diabetics on a group basis, but not on individual results. The greatest increase in platelet adhesiveness was demonstrated in patients with ischaemic heart disease and diabetes. Increased platelet adhesiveness was seen in individuals of both diabetic and control groups, in whom no clinical or electrocardiographic evidence of ischaemic heart disease was found. This finding is discussed, also the relationship between platelet adhesiveness levels and the age, sex, duration of disease, blood glucose and serum lipid levels of the diabetic patients.
\end{abstract}

Adhésivité des plaquettes, taux de fibrinogène plasmatique et de facteur VIII dans le diabète sucré

Résumé. L'adhésivité des plaquettes et les taux de deux facteurs de coagulation, le fibrinogène et le facteur VIII, ont été étudiés chez un groupe de diabétiques et chez des sujets témoins. Les trois mesures étaient significativement anormales chez les sujets diabétiques. L'augmentation de l'adhésivité des plaquettes permettait de distinguer les diabétiques sur une base de groupe, mains non d'après des résultats individuels. L'augmentation la plus grande de l'adhésivité des plaquettes a été démontrée chez les sujets atteints de maladie de coeur ischémique et de diabète. Une adhésivité accrue des plaquettes a été observée à la fois chez des individus du groupe diabétique et du groupe témoin, chez lesquels on n'a trouvé aucun signe clinique ou électrocardiographique de maladie de coeur ischémique. Ce résultat est discuté, ainsi que la relation entre les taux d'adhésivité des plaquettes et l'âge, le sexe, la durée de la maladie, la glycémie et les taux de lipides du sérum chez les sujets diabétiques.

Die Thrombocyten-Adhäsivität und die Spiegel von Fibrinogen und Faktor VIII im Plasma von Diabetikern Zusammenfassung. Die Plättchen-Adhäsivität und die Spiegel zweier Coagulations-Faktoren, Fibrinogen und Faktor VIII wurden bei einer Serie von Diabetikern und nichtdiabetischen Vergleichspersonen untersucht. Die Zunahme der Thrombocyten-Adhäsivität ließ eine Abgrenzung der Diabetiker als Kollektiv, nicht aber für Einzelpersonen zu. Der stärkste Anstieg der PlättchenAdhäsivität fand sich bei Diabetikern mit coronarer Minderdurchblutung. Ein solcher Anstieg ließ sich aber auch bei Diabetikern und Vergleichspersonen nachweisen, bei denen keine klinischen oder elektrokardiographischen Zeichen einer ischämischen Herzerkrankung bestanden. Dieser Befund wird diskutiert ebenso wie die Beziehungen zwischen Thrombocyten-Adhäsivität und Alter, Geschlecht, Krankheitsdauer, sowie Blutzucker- und Blutfettspiegeln der Diabetiker.

Key-words: Diabetes, blood platelets, adhesiveness, fibrinogen, factor VIIT, ischaemic heart disease, blood glucose, serum lipids.
The occurrence of intravascular thrombosis as a frequent and important complication in patients with diabetes mellitus has been well documented [11, 21, 31]. It has been suggested that in the diabetic the amount of arterial wall disease is increased [2, 20, 32]. This has been challenged by Eakins [6] and by Mitchell and Schwartz [24]. The presence of serum lipid abnormalities in diabetes [1] and the association of abnormal blood coagulation in subjects with disordered fat metabolism [29, 25], has focussed attention on the coaguability of the diabetics' blood as a factor in the high incidence of thrombosis.

In recent years it has become apparent that the blood platelet plays a central role in the initiation of intravascular thrombosis [10]. One aspect of platelet behaviour that can be measured is the ability to adhere to a foreign surface. This would seem meaningful because in a wide variety of disorders, such as ischaemic heart disease [22, 23], postpartum [34] and postoperative states $[12,34]$ in which there is a high incidence of thrombosis, the degree of platelet adhesiveness has been found to be increased. Many techniques have been used to measure platelet adhesiveness and those first described by Payling Wright [33] - the rotating bulb technique - and by Hellem [14] - the glass bead. column technique - seem reliable. Hirsch and $\mathrm{Mc}$ Bride [16] found these two techniques to give similar results. We have confirmed this finding in a preliminary survey with 30 subjects, studied by the two methods, (Correlation coefficient $r=0.8452$ giving $P=0.0001$ ). In this paper we report on a study of these tests of platelet adhesiveness in diabetes mellitus and attempt to correlate the findings with various aspects and complications of the disease and with the level of certain coagulation factors.

\section{Clinical Material}

A total of 235 patients with diabetes mellitus and 165 nondiabetic subjects, as a control group, were studied. Amongst the diabetic subjects, 140 aged 8 to 85 years were newly diagnosed; electrocardiographs were carried out on all these patients and in 27, significant abnormalities were found. Forty-five diabetic subjects had major complications other than ischaemic 
heart disease, such as nephropathy, retinopathy and peripheral vascular disease. The remaining 50 diabetic subjects had no major complication but had been diagnosed for 3 months to 30 years.

The control group of 165 non-diabetic subjects was made up of 140 subjects with no significant illness and 25 who had presented with signs and symptoms of ischaemic heart disease. The 140 were selected from healthy hospital staff, patients attending a medical outpatient department for such complaints as simple goitre, investigation of minor intestinal or psychoneurotic symptoms and from a dental outpatient clinic. These subjects had no family history of diabetes mellitus, and either had a normal postprandial blood sugar or a normal response to a $50 \mathrm{~g}$ oral glucose tolerance test. Except for the group of 25 selected for the
McDonald and Edgill [22], or by the glass bead column method of Hellem [14] as modified by Hirsch and McBride [17].

3. Blood glucose [18] as modified for the Auto-Analyzer.

4. Serum cholesterol [35] as modified for the AutoAnalyzer.

5. Serum triglycerides [13].

6. Plasma fibrinogen [27].

7. Factor VIII assay [30].

\section{Results}

The results of platelet adhesiveness in the 140 newly diagnosed diabetics and the same number of age and sex matched controls are shown in Fig. 1. The mean percentage of adhesive platelets for the diabetic pa-

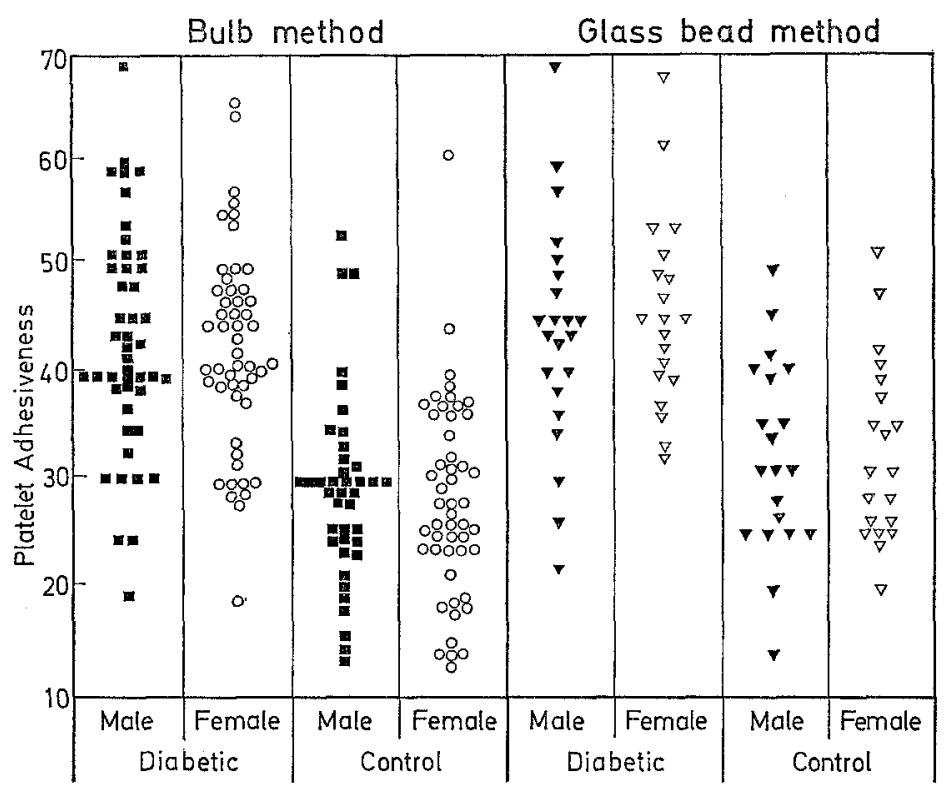

Fig. 1. Platelet adhesiveness in the diabetic and control subjects

presence of symptoms of ischaemic heart disease, the control patients had no clinical evidence of vascular diseaes or abnormal electrocardiographic patterns. The 25 patients with ischaemic heart disease had normal glucose tolerance tests and no history of diabetes.

\section{Methods}

The patients were all studied $2-21 / 2 \mathrm{~h}$ after their last meal and after a 20 -minute rest period, with the exception of those having certain lipid investigations in which case the appropriate tests were carried out in the fasting state. Blood samples were all taken by the same person using a minimal degree of venous occlusion. Siliconised equipment was used throughout.

The following measurements were carried out:

1. Platelet count [3].

2. Platelet adhesiveness, either by the rotating bulb technique of Payling Wright [33] as modified by tients, using the rotating bulb technique, was 42 per cent with a range of 20 to 70 per cent, whereas for the non-diabetics it was 29 per cent with a range of 14 to 60 per cent. Using the glass bead column method the figure for the diabetics was 45 per cent with a range of 23 to 69 per cent and for the non-diabetics, 32 per cent with a range of 15 to 52 per cent.

Although these results show a significant difference between diabetic and non-diabetic groups $(0.01>P$ $>0.001$ ), maximal and minimal levels of platelet adhesiveness were found amongst individuals of either groups. It is also apparent from Fig. 1 that the sex of the subject did not influence the level of platelet ad. hesiveness.

\section{Follow-up of Patients After Treatment}

Platelet adhesiveness studies were repeated in 66 patients after a $3-4$ month period of treatment, and 
analysis revealed that a decrease of platelet adhesiveness was only of significance in the small group of female patients treated with diet alone $(0.01>P \vec{P}>$ 0.001). Sulphonylureas and insulin therapy did not significantly alter the platelet adhesiveness level.

\section{Patients with Major Complications}

Twenty-seven of the 140 newly diagnosed diabetic patients had electrocardiographeo evidence of ischaemic heart disease. The mean value of adhesive platelets for the group was 50 per cent, whereas in a group of 25 age-sex-matched non-diabetic patients, with a comparable degree of myocardial ischaemia, it was 43 per cent ( $P$ value 0.001 ).

A further 13 patients had peripheral vascular disease. An additional 24 patients had ophthalmic complications; 14 having moderate to severe retinopathy and 10 cataracts affecting one or both eyes. Finally, 8 patients with ozotaemia and proteinuria, 6 of whom had associated hypertension, their diastolic pressure being $95 \mathrm{~mm} \mathrm{Hg}$ or more, were investigated. The

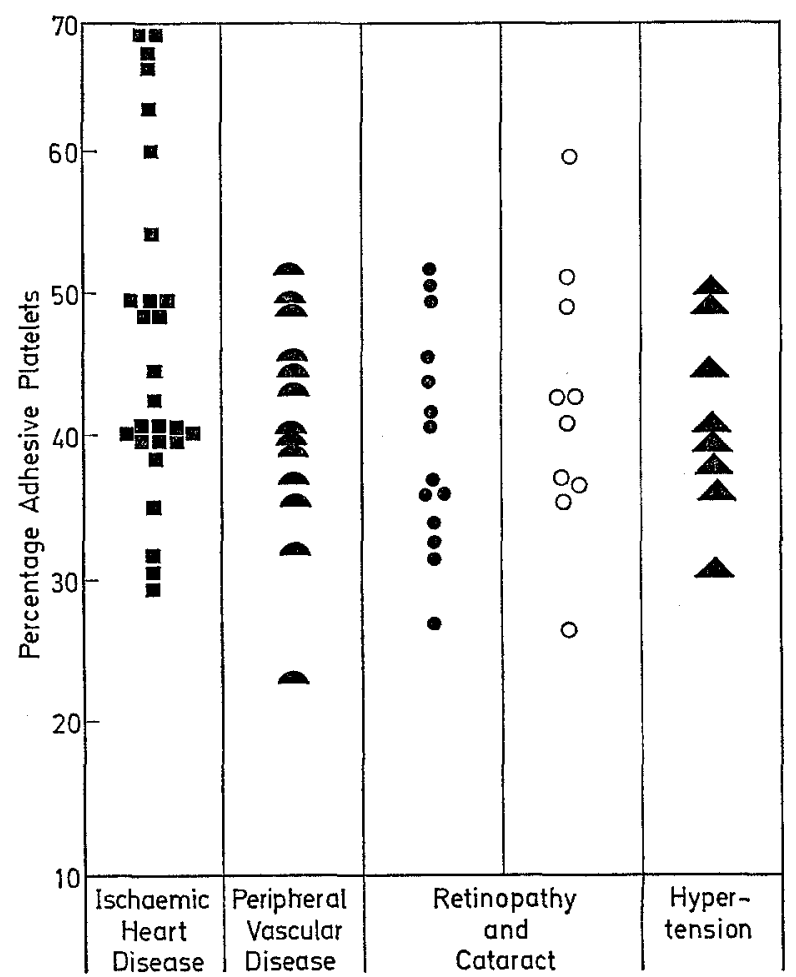

Fig. 2. Platelet adhesiveness in diabetics with complications

results are illustrated in Fig. 2. It can be seen that the increase in adhesiveness described in the newly diagnosed diabetic patient was maintained in the presence of complications, and that the greatest increase was seen in the patients with ischaemic heart disease in addition to diabetes.
Correlation of Platelet Adhesiveness to the Duration of the Disease and the Levels of Blood Glucose and Serum Cholesterol

In 50 patients the level of platelet adhesiveness was correlated with the duration of the disease, which varied from 3 months to 32 years; the distribution of results was random $(r=0.12)$. Regression equations, calculated between the level of blood glucose, either at the time of diagnosis or following stabilization and platelet adhesiveness, were $r=0.18$ and 0.20 respectively. Similarly, the level of cholesterol in 98 untreated diabetics, when related to the respective mean values of platelet adhesiveness, did not exhibit any positive correlation $(r=0.22)$.

Platelet Adhesiveness and Serum Triglyceride Levels

The mean serum triglyceride level in 16 untreated diabetics was $249 \mathrm{mg}$ per cent and in a similar number of controls, $95 \mathrm{mg}$ per cent $(0.02>P>0.01)$. Although the mean platelet adhesiveness was higher in the diabetic group, 42 per cent as compared with 29 per cent in the individual subjects, there was no association between triglyceride levels and platelet adhesiveness in either the diabetics or the controls $(r=0.26)$. VIII)

Coagulation Factor Levels (Fibrinogen and Factor

The mean fibrinogen level for the 28 male diabetics was $389 \mathrm{mg} / 100 \mathrm{ml}$ plasma, whereas for a control group it was $295 \mathrm{mg} / 100 \mathrm{ml}$ plasma; for 27 fomales the respective figures were 384 and $291 \mathrm{mg} / 100 \mathrm{ml}$. In both males and females the differences between the diabetic and non-diabetic patients were significant $(P=0.001)$. The fibrinogen results were plotted against corresponding values for percentage platelet adhesiveness in diabetic and control patients but no relationship was found $(r=0.11)$. In 50 diabetic patients, after stabilization, the mean levels for plasma fibrinogen were $355 \mathrm{mg} / 100 \mathrm{ml}$ for males and $378 \mathrm{mg} / 100 \mathrm{ml}$ for females. These results did not differ statistically from the original findings.

Factor VIII assays were carried out; they showed that untreated diabetic patients had significantly increased values of this coagulation factor, the mean level for 30 such patients being 140 per cent, and 97 per cent for the controls $(P=0.001)$. Furthermore, the diabetic patients, affer treatment, still maintained their elevated Factor VIII values with a mean level of 135 per cent. A statistical analysis of the relationship between platelet adhesiveness and Factor VIII levels in diabetic subjects was not significant $(r=0.29)$.

\section{Discussion}

Platelet adhesiveness was studied in a series of patients with diabetes mellitus. This aspect of platelet function was capable of distinguishing diabetics from non-diabetics on a group basis, on account of the 
former's increased levels of platelet adhesiveness. However, individuals could not be correctly assigned to either group purely on the results of the test. In addition to the finding of altered platelet function, the levels of two plasma coagulation factors were found to be significantly elevated in the diabetic patients. This finding, in association with the increase in platelet adhesiveness, lends a measure of support to the concept that a hypercoagulable state exists in diabetes mellitus and that it may contribute to the increased incidence of occlusive vascular disease observed in the condition.

A positive relationship did not exist between the duration of the disease, the age or sex of the patients and the actual levels of platelet adhesiveness, plasma fibrinogen or factor VIII. Treatment with insulin or chlorpropamide did not significantly reduce the $a b$ normal level of platelet adhesiveness or alter the plasma fibrinogen or factor VIII levels. A significant reduction in the platelet adhesiveness results, but not in the level of fibrinogen or factor VIII, was found in 10 female patients who were treated by diet alone. The increase in plasma fibrinogen levels confirmed earlier work carried out by Egeberg [8]. Eastham and Morgan [7] have described similar changes in non-diabetic patients with ischaemic heart disease.

In view of the metabolic relationship between carbohydrate and lipid metabolism, it was expected that some association might be found between the increase in platelet adhesiveness, the blood glucose and one or more of the lipid parameters studied. However, in respect of the blood glucose, cholesterol and triglycerides, no association was established. Although these general studies did not show any correlation with platelet adhesiveness, it is important to note that the presence of ischaemic heart disease in both diabetic patients and in control subjects was well correlated with the increased platelet adhesiveness levels, as described by Katz et al. [19, 20], McDonald et al. [22], and Owren [28]. However, both occasional control and diabetic subjects were encountered with comparable increased levels of platelet adhesiveness and in whom no evidence of vascular disease could be found. This lack of correlation remains unexplained.

Increased platelet adhesiveness in diabetic patients has been described by other workers. Hellem et al. [15] found that the platelets in 25 insulin-treated patients displayed abnormal adhesiveness only when exposed to the action of the nucleotide, adenosine di-phosphate. Breddin [4] investigated a series of 200 patients, although his techniques were different from those used here and to the methods used by the majority of workers in the field of platelet research; he found his platelet agglutination test to be significantly abnormal in patients with diabetes mellitus. Owren [28], using the glass bead column technique of Hellem [14], demonstrated an increase in platelet adhesiveness in 50 diabetic patients, but did not specify their age, mode of treatment, or the duration of their disease. Thus, from this present work, which is an extension of earlier work by Bridges et al. [5], it is clear that increased platelet adhesiveness is a common finding in diabetes. This study attempted not onlly to measure the platelet adhesiveness in all phases of the disease, but also to investigate the inter-relationships between the biochemical abnormalities and any alteration in platelet behaviour. The results are of a relatively negative nature, but they have served to emphasise the difficulties in correlating dynamic changes in vivo with the results of a comparatively artifactual laboratory test in vitro, which, although crude, was capable of demonstrating a sustained but as yet unexplained abnormality in a large series of patients with diabetes mellitus.

\section{References}

1. Albrink, M.J., Lavietes, P.H., Man, E.B.: Vascular disease and serum lipids in diabetes mellitus. Ann. intern. Med. 58, 305-323 (1963).

2. Bell, E.T.: A postmortem study of vascular disease in diabetes. Arch. Path. 53, 444-455 (1952).

3. Brecher, G., Cronkite, E.P.: Morphology and enumeration of human blood platelets. J. appl. Physiol. 3, $365-377$ (1950).

4. Breddin, von K.: Über die gesteigerte Thrombocytenagglutination bei Gefäßkrankheiten. Schweiz med. Wschr. 95, 655-660 (1965).

5. Bridges, J.M., Dalby, A.M., Millar, J.H.D., Weaver, J.A.: The effect of D-glucose on platelet stickiness. Lancet 1964 I, $75-77$.

6. Eakins, D.: Studies in atherosclerosis. M.D. Thesis, The Queen's University of Belfast (1963).

7. Eastham, R.D., Morgan, E.H.: Plasma fibrinogen levels in coronary artery disease. Lancet $1963 \mathrm{II}$, $1196-1197$.

8. Egeberg, O.: The blood coagulability in diabetic patients. Seand. J. clin. Lab. Invest. 15, 533-538 (1963).

9. Fearnley, G.R., Chakrabarti, R., Avis, P.R.D.: Blood fibrinolytic activity in diabetes mellitus and its bearing on ischaemic heart disease and obesity. Brit. med. J. 1963 I, 921-923.

10. Glynn, M.F., Murphy, E. A., Mustard, J.F.: Platelets and thrombosis (editorial). Ann. intern. Med. 64, $715-719$ (1966).

11. Goldenberg, S., Alex, M., Blumenthal, H.T. : Sequelae of arteriosclerosis of the aorta and coronary arteries. Diabetes 7, 98-108 (1958).

12. Ham, J.M., Slack, W.W.: Platelet adhesiveness after surgery. Brit. J. Surg. 54, 385-389 (1967).

13. van Handel, E., Zilversmit, D.B.: Micromethod for direct estimation of serum triglyceride. J. Lab. clin. Med. 50, 152-157 (1957).

14. Hellem, A.J.: The adhesiveness of human blood platelets in vitro. Scand. J. clin. Lab. Invest. 12, Suppl. 51, 1-117 (1960).

15. - Skalhegg, B.A., Odegaard, A.E.: The platelet adhesiveness in plasma from diabetic and lipemic patients. Sangre (Barcelona) 9, 175-177 (1964).

16. Hirsch, J., McBride, J.A., Wright, H.P.: Platelet adhesiveness: A comparison of the rotating bulb and glass bead column methods. Thrombos. Diathes. haemorrh. (Stuttg.) 16, 100-104 (1966).

17. - MoBride, J.A.: Increased platelet adhesiveness in recurrent venous thrombosis and pulmonary embolism. Brit. med. J. 1965 II, 797-799.

18. Hoffman, W.S.: Rupid photoelectric method for determination of glucose in blood and urine. J. biol. Chem. $120,51-55(1937)$. 
19. Katz, A.M., MeDonald, L., Davies, B., Edgill, M.: Fibrinolysis and blood coagulation in ischaemic heart disease. Lancet 1963 I, 801-805.

20. LeCompte, P.M. : Vascular lesions in diabetes mellitus. J. ehron. Dis. 2, 178-219 (1955).

21. Marks, H.H.: Longevity and mortality of diabetics. Amer. J. publ. Hlth. 55, 416-423 (1965).

22. MoDonald, L., Edgill, M.: Dietary restriction and coagulability of the blood in ischaemic heart disease. Lancet 1958 I, 996-998.

23. - - Changes in the coagulability of the blood or during various phases of ischaemic heart disease. Lancet $1959 \mathrm{I}, 1115-1118$.

24. Mitchell, J. R.A., Schwartz, C. J. : In : Arterial Disease* Blackwell Scientific Publications Ltd. (1965).

25. Murphy, E.A., Mustard, J.F.: Coagulation tests and platelet economy in atherosclerotic and control subjects. Circulation 25, 114-125 (1962).

26. O'Brien, J.R.: The mechanism and prevention of platelet adhesion and aggregation considered in relation to arterial thrombosis. Blood 24, 309-314 (1964).

27. Ogston, C.MI., Ogston, D.: Plasma fibrinogen and plasminogen levels in health and ischaemic heart disease. J. clin. Path. 19, 352-356 (1966).

28. Owren, P.A.: Coronary thrombosis: its mechanism and possible prevention by linolenic acid. Ann. intern. Med. 63, 167-184 (1965).
29. Philip, R.B., Wright, H.P.: Effect of adenosine on platelet adhesiveness in fasting and lipaemic bloods. Lancet 1965 II, 208-209.

30. Pitney, W.R.: The assay antihaemophilic globulin in plasma. Brit. J. Haemat. 2, 250-254 (1956).

31. Root, H.F., Bland, E.F., Gordon, W.H., White, P.D. Coronary atherosclerosis in diabetes mellitus. J. Amer. med. Ass. 113, 27-30 (1939).

32. Stearns, S., Schlesinger, M.J., Ruby, A.: Incidence and clinical significance of coronary artery disease in diabetes mellitus. Arch. intern. Med. 80, 463-474 (1947).

33. Wright, Helen P.: The adhesiveness of blood platelets in normal subjects with varying concentrations of anticoagulants. J. Path. Bact. 53, 255-262 (1941).

34. - Changes in adhesiveness of blood platelets following parturition and surgical operations. J. Path. Bact. $54,461-468$ (1942).

35. Zlatkis, A., Zak, B., Boyle, A.J.: New method for direct determination of cholesterol. J. Lab. clin Med. 41, $486-492$ (1953).

Dr. E. Mayne

Dept. of Clinical Pathology

and Sir George E. Clark Metabolic Unit Royal Victoria Hospital

Belfast, Northern Ireland 